\section{Historical utilization of wood in southeastern Moravia (Czech Republic)}

\author{
Vera Filková, Tomáš Kolár, Michal Rybníček, Vladimír Gryc, Hanuš \\ Vavrčík, Josef Jurčík
}

In the present study, anatomical features were used to identify tree species chosen to craft farming tools from the $19^{\text {th }}$ and first half of the $20^{\text {th }}$ century preserved in specimen inventories of the open-air museum in Strážnice, southeastern Moravia (Czech Republic). In total, 701 samples from 337 historical farming tools were obtained from museum specimens. The samples were identified at micro- or macroscopic levels, or both. Results indicated local people used floodplain forest wood to construct farming tools in the study region. Nineteen wood species were identified; from this total, those with higher densities and better mechanical properties were used to manufacture tools, and included predominantly beech, oak, and ash. Softwood species, with lower densities were mainly used for chiseled out implements. We hypothesized regional forest species composition played an essential role in woody species choice, however the species also possessed appropriate properties. Cultivated tree species, such as fruit trees, were employed to create common objects; however, currently, these species are typically applied for special purposes. We concluded an increased number of species were employed in the past for utilitarian purposes, including tree species grown outside local forest boundaries, including cultivated fruit tree species; and species were utilized with good, although perhaps tacit, knowledge of their properties.

Keywords: Farming Tools, Forest Species Composition, Open-air Museum, South-eastern Moravia, Wood Identification

\section{Introduction}

Wood has always been an integral material in human life. Initially, humans employed species found in their local surroundings; subsequently, through trial and error, people acquired knowledge regarding which species were appropriate for specific uses. Species eventually became locally unavailable due to human exploitation, and people acquired suitable species through trade or in markets. The availability of new species was also influenced by timber floating in areas along rivers (Holec 1971, Vinař et al. 2005, Eckstein \& Wrobel 2007). Today, the timber trade has allowed producers to choose from among many species suitable for a variety of wood products.

Until the $18^{\text {th }}$ century in Central Europe, trees were used based on species properties, for example, birch was used for wheels (stakes, shafts, and fellies), maple for joiners, oak for casks and mills, and fir for shingles, among many other examples (Havelka 1928, Průša 1990, Němec et al. 2005). Following the Industrial Revolution and the heavy deforestation that occurred in Europe as a consequence, only the most economical species were planted. In the case of the Czech Republic, the "Forest Order for Bohemia and Moravia" was published in 1754 , promoting pine and spruce. Con- sequently, these were the primary species planted during the $19^{\text {th }}$ century (Lipský 2000), and dominant forest tree species composition underwent a notable simplification. Tab. 1 shows a comparison of the historic "native" and current species composition in the Czech Republic. Nowadays, there are efforts in sustainable development and sustainable materials use, which should be effective in beneficial application of all tree species and forests. In addition, a high proportion of coniferous forest communities are being converted into more natural mixed forests with increased diversity (Tarp et al. 2000).

Knowledge of historic human wood utilization is gradually being lost; therefore, our study intended to determine which species people used to craft various wood products. Reconstructing this history could provide an understanding of the tree species best suited to produce different wood products, and why specific species were chosen. Consequently, elucidating the valuable properties in these species might generate information for present day wood product production.

Here, we present results from wood anatomical identifications of species used to construct farming, garden, and kitchen implements from museum specimens. All specimens were preserved in inventories of the $\square$ Department of Wood Science, Faculty of Forestry and Wood Technology, Mendel University in Brno, Zemedelská 3, 613-00 Brno (Czech Republic)

@ Vera Filková (vera.filkova@gmail.com)

Received: Jul 30, 2013 - Accepted: Nov 20, 2013 - Final Acceptance: Apr 28, 2014

Citation: Filková $V$, Kolár $T$, Rybníček $M$, Gryc V, Vavrčík H, Jurčík J, 2015. Historical utilization of wood in south-eastern Moravia (Czech Republic). iForest 8: 101-107 [online 2014-05-07] URL: http: / /www.

sisef.it/iforest/contents/?id=ifor1091-007

Communicated by: Raffaele Lafortezza

open-air museum in Strážnice, southeastern Moravia (Czech Republic - Fig. 1). The objectives of this paper were to analyze the wood species used to craft utilitarian tools in this region; compare results with the existing literature; and consider explanations why these specific species were chosen to construct the implements based on species physical and mechanical properties.

\section{Materials and Methods}

\section{Study area}

The wooden tool and implement samples we examined are housed in the Museum of Villages of south-east Moravia, located in Strážnice, a village in southeastern Czech Republic. The objects were collected throughout the region, which is their pro-

Tab. 1 - Native (historic) and current forest tree species composition in the Czech Republic (\% of forest area - UHUL 2013).

\begin{tabular}{lcc}
\hline \multicolumn{1}{c}{ Species } & $\begin{array}{c}\text { Native } \\
\text { species } \\
\text { composition } \\
\mathbf{( \% )}\end{array}$ & $\begin{array}{c}\text { Current } \\
\text { species } \\
\text { composition } \\
\mathbf{( \% )}\end{array}$ \\
\hline Picea spp. & 11 & 55.2 \\
Abies spp. & 18 & 0.9 \\
Pinus spp. & 5.4 & 18 \\
Larix spp. & 0 & 3.7 \\
Other conifers & 0 & 0.2 \\
Total conifers & 34.4 & 78 \\
\hline Quercus spp. & 17.2 & 6.3 \\
Fagus spp. & 37.9 & 5.8 \\
Carpinus spp. & 1.8 & 1.2 \\
Fraxinus spp. & 0.7 & 1 \\
Acer spp. & 1.5 & 0.8 \\
Ulmus spp. & 0.5 & 0 \\
Betula spp. & 1.1 & 3 \\
Tilia spp. & 3.8 & 0.9 \\
Alnus spp. & 0.6 & 1.5 \\
Other & 0.5 & 1.5 \\
broadleaved & & \\
Total & 65.6 & 22 \\
broadleaved & & \\
\hline
\end{tabular}




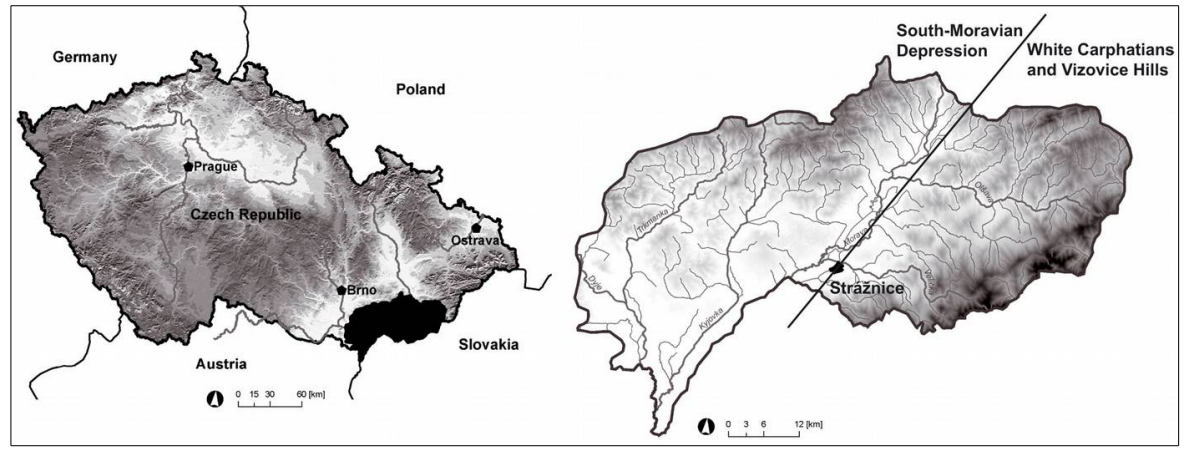

Fig. 1 - Geographic map of the Czech Republic with the study region highlighted in black (left). The black crossing line (right) indicates the border of the two relevant natural forest areas in the study region.

bable place of origin, although some may have been purchased in local markets. The ethnographic literature calls the region Slovácko, and includes two natural forest areas: Jihomoravské úvaly (the South-Moravian Depressions), and Bilé Karpaty a Vizovické vrchy (the White Carpathians and Vizovice Hills). The village of Strážnice is located directly on the border between these two topographic regions (Fig. 1). The South-Moravian Depressions are located in an area consisting of broad, flat lower river areas with small altitudinal differences (150-344 m a.s.1.). The regional climate is warm and moderately to very dry, with mild winters. The predominant species in the floodplains include oak (Quercus), ash (Fraxinus), hornbeam (Carpinus), and beech (Fagus). Wet soil species include birch (Betula), alder (Alnus), willows (Salix), and poplars (Populus), which are characteristic of wetlands and riparian zones (Průša 1990). In contrast, the
White Carpathians are a mountainous band with peaks of approximately $900 \mathrm{~m}$ a.s.l. The climate is mildly warm and moist. The forest proportion in the mountains is approximately $40 \%$; and the predominant species include oak, beech, hornbeam, and maple (Acer Průša 1990).

\section{Study samples}

In total, we sampled 337 wood farm tools and garden and kitchen implements representing the study area. Some of these products consisted of multiple components, which we counted as separate samples, for a total of 701 samples. The specimens included planked wooden washtub troughs; peels (bread shovels); wooden buckets and pails for bread dough, lard, meat, and cheese; wooden buckets used to measure grains; rakes; a scythe for grains; ash rakes; pitchforks for hay, and pitchforks for manure and beets; flails; gambrels (hog-butchering han- gers); freight sledges; frame saws; and twohanded saws (Fig. 2). The products in the open-air museum were collected from surrounding villages, and we assumed the preserved products were constructed between the $19^{\text {th }}$ and $20^{\text {th }}$ centuries.

\section{Species identification}

The selected tool samples were used for species anatomical wood identification. Individual tree species exhibit varying degrees of difference in wood anatomical structure. These differences are manifested at microand macroscopic levels. Identification using wood is usually possible to the genus, and occasionally the species level (Vavrčík \& Gryc 2004). However, in this paper we use the term "species" to indicate either a species or a group of species belonging to the same genus and sharing similar wood features, as commonly used in wood anatomical studies. Macroscopic identification requires a relatively large piece of wood, so that all macroscopic features are visible (Hoadley 1990). Furthermore, wooden products preserved in open-air museums are often blackened by age and dust, and sometimes treated by preservation agents, therefore macroscopic identification is often impossible. In spite of these potential challenges, in each case, we attempted identification based on wood macroscopic features. When this was not possible (usually only ring-porous species could be identified through macroscopy), we based wood identification on microscopic structure examination, which is more suitable and definitive (Ives 2001). Only a small piece of wood is necessary for microscopic identification. Small wood splinters were collected so samples were damaged as little as pos-

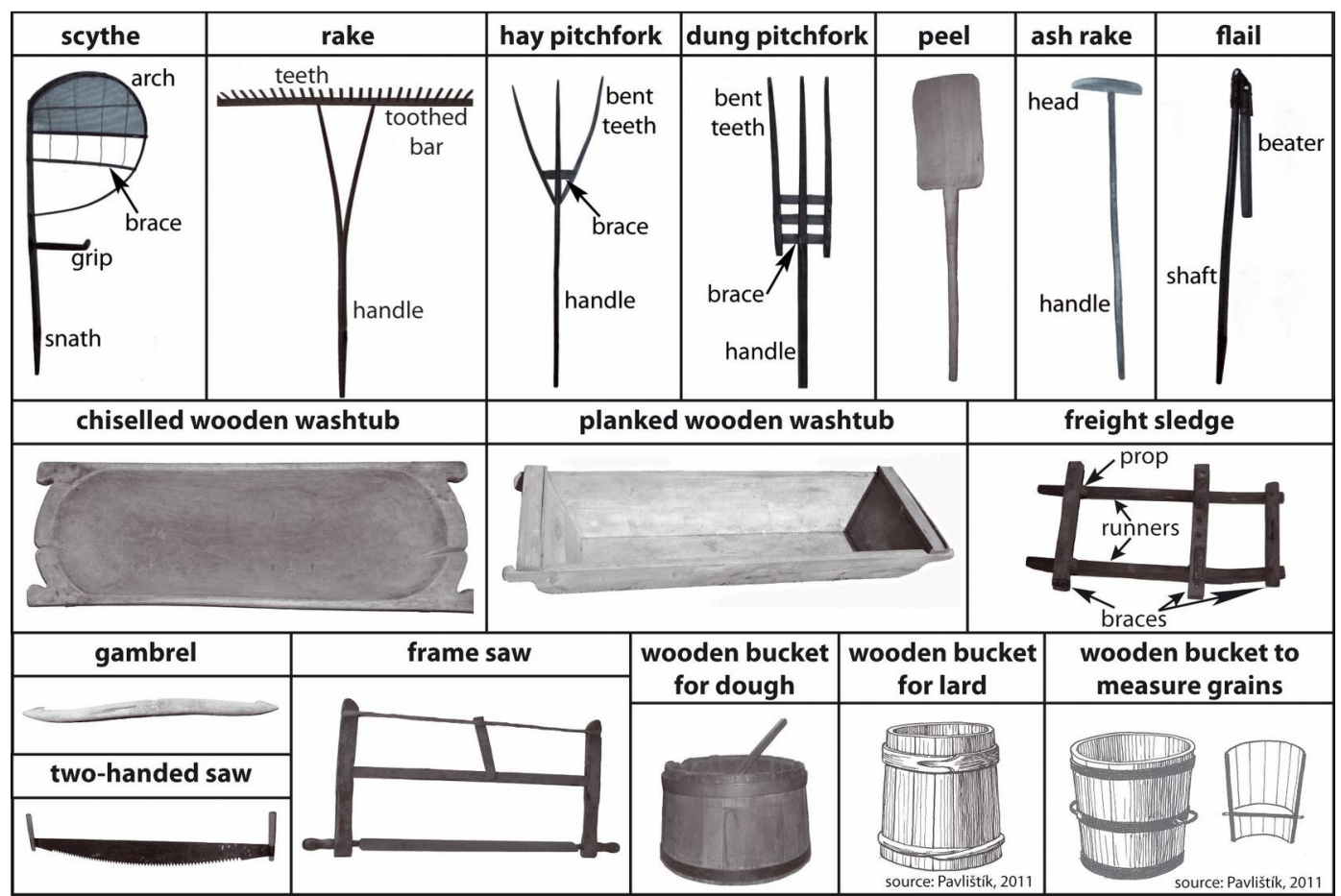

Fig. 2 - Diagrammatic representation of museum specimens. 
sible, and taken from areas hidden from common view. In the laboratory, the splinters were cut with razor blades into three sections (tangential, radial, and cross sections) necessary for identification. These sections were used for temporary microscopic examination using water as the mounting medium (Vavrčík \& Gryc 2004). The samples were observed under a Leica DMLS light microscope for identification. Wood species were identified using methods established by Schweingruber (1990) and IAWA Committee (1989).

\section{Results}

A total of 19 species were identified, including two softwood, four ring-porous hardwood, and 13 diffuse-porous or semi-ringporous (included in the diffuse-porous group) species (Fig. 2, Tab. 2, Tab. 3, Tab. 4, and Tab. 5).

We observed 93 containers crafted by chiseling, the largest of these was used for hog butchering (11 containers); the smaller vessels were used for other farm and household purposes, including dough making (81 variously sized and shaped containers); and one container had holes, which served as a sieve. The chiseled containers were primarily crafted from poplar (70 containers). Other species chosen to construct farm and household utilitarian items included willow (15 samples), maple, and linden (Tilia). Wooden tubs and a manger made from planks were also among the samples. These planked containers were made of spruce (Picea - 3) and fir (Abies - 2). Chiseled bread peels made predominantly from one piece of beech were also among the specimens (31 whole and partial peel specimens - Tab. 2).

Tab. 2 - Chiseled and planked wooden product results.

\begin{tabular}{|c|c|c|c|c|c|c|c|c|c|c|c|}
\hline Product & Part of product & 怘 & 芯 & $\frac{\mathfrak{\Xi}}{\stackrel{\Xi}{\Xi}}$ & ङ & 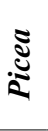 & $\underline{\mathbf{s}}$ & 节 & $\stackrel{\tilde{\vartheta}}{\nabla}$ & : & 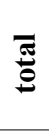 \\
\hline \multirow[t]{3}{*}{ wooden wash tub } & chiselled - for hog & - & - & 9 & - & - & - & 1 & - & 1 & 11 \\
\hline & chiselled - other purposes & - & - & 60 & 1 & - & - & 14 & - & 6 & 81 \\
\hline & chiselled - sieve & - & - & 1 & - & - & - & - & - & - & 1 \\
\hline planked tub & - & - & - & - & - & 3 & - & - & 2 & - & 5 \\
\hline \multirow[t]{3}{*}{ bread peel } & whole & 20 & 2 & 5 & 1 & - & 1 & - & - & - & 29 \\
\hline & handle & - & - & - & - & - & 1 & - & - & - & 1 \\
\hline & head & - & - & 1 & - & - & - & - & - & - & 1 \\
\hline
\end{tabular}

Tab. 3 - Coopers' product results.

\begin{tabular}{llcccc}
\hline Product & Part of product & Fraxinus & Quercus & Coniferous & Total \\
\hline Wooden & for bread dough & - & 16 & - & 16 \\
bucket & for lard & - & 28 & 1 & 29 \\
& for lard - lid & 1 & 3 & 1 & 5 \\
& to measure corn - body & - & 11 & - & 11 \\
& to measure corn - bottom & - & 11 & - & 11 \\
\hline
\end{tabular}

Samples included 56 buckets and pails, some with lids, constructed by coopers, and nearly all from oak (Tab. 3). Sixteen containers were used for bread dough, 29 for lard, meat or cheese, and one for corn.

Handled tools included 18 rakes, with a total rake sample size of 65 , as the rakes were subdivided into handles, toothed bars, and teeth. Additionally, if a tooth appeared to have been repaired, we sampled the repair as well. Some rake handles consisted of two sticks with braces in the middle. Beech and ash comprised most handles (8 and 7 handles, respectively). The toothed bars and teeth were predominantly crafted from beech. Beech was primarily chosen to con- struct the middle rake braces (9 in total Tab. 4). Seven rakes were made exclusively from beech; however one rake had a repaired tooth made of oak. The style of two rakes consisted of two sticks and braces. Other rakes were made from two or even three different species combinations. One of the samples was determined to mark lines in the field prior to planting or sowing, and was made of poplar (handle) and oak (teeth and bar).

There were six ash rakes, consisting of 11 parts (handles and heads). The handles were constructed primarily of spruce. The rake heads were made of oak (2), pear (Pyrus), beech, and fir (1 head per species - Tab. 4).

Tab. 4 - Wooden handled and gambrel product results.

\begin{tabular}{|c|c|c|c|c|c|c|c|c|c|c|c|c|c|c|c|c|c|c|c|c|}
\hline Product & $\begin{array}{l}\text { Part of } \\
\text { product }\end{array}$ & 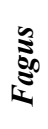 & 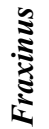 & $\begin{array}{c}0 \\
\vdots \\
\vdots \\
\vdots \\
\vdots \\
0\end{array}$ & $\frac{\mathfrak{s}}{\mathfrak{s}}$ & $\underset{\mathfrak{s}}{\stackrel{5}{\mathbf{s}}}$ & ฮे & 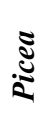 & $\underset{\mathbf{s}}{\mathfrak{s}}$ & : & 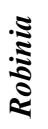 & $\frac{\tilde{u}}{\nabla}$ & $\underset{N}{: \mathbb{N}}$ & 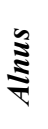 & $\stackrel{\mathfrak{\Sigma}}{\mathbf{a}}$ & $\frac{\mathfrak{s}}{3}$ & $\underset{\mathbf{5}}{\mathbf{5}}$ & 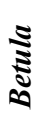 & $\frac{2}{5}$ & 퐁 \\
\hline \multirow[t]{3}{*}{ pitchfork } & handle & 19 & 14 & 1 & - & - & 1 & - & - & - & - & - & - & - & - & - & - & - & - & 35 \\
\hline & side tooth & 33 & 35 & - & - & - & 6 & - & - & - & - & - & - & - & - & - & - & - & - & 74 \\
\hline & brace & 25 & 12 & - & - & - & 1 & - & 3 & - & - & - & - & - & - & - & - & - & - & 41 \\
\hline \multirow[t]{4}{*}{ rake } & handle & 8 & 7 & - & - & 1 & - & - & 1 & - & - & - & 2 & - & - & - & - & - & - & 19 \\
\hline & toothed bar & 11 & 4 & 1 & - & - & - & - & 1 & - & - & - & 1 & - & - & - & - & - & - & 18 \\
\hline & tooth & 8 & 4 & 4 & - & - & - & - & - & - & - & - & - & - & 1 & - & - & 1 & 1 & 19 \\
\hline & brace & 7 & - & 1 & 1 & - & - & - & - & - & - & - & - & - & - & - & - & - & - & 9 \\
\hline \multirow[t]{3}{*}{ liner } & handle & - & - & - & 1 & - & - & - & - & - & - & - & - & - & - & - & - & - & - & 1 \\
\hline & toothed bar & - & - & 1 & - & - & - & - & - & - & - & - & - & - & - & - & - & - & - & 1 \\
\hline & tooth & - & - & 1 & - & - & - & - & - & - & - & - & - & - & - & - & - & - & - & 1 \\
\hline \multirow[t]{2}{*}{ ash rake } & handle & 1 & - & - & - & - & - & 4 & - & 1 & - & - & - & - & - & - & - & - & - & 6 \\
\hline & head & 1 & - & 2 & - & - & - & - & - & - & - & 1 & - & - & 1 & - & - & - & - & 5 \\
\hline \multirow[t]{3}{*}{ flail } & handle & 8 & 6 & 1 & 3 & - & 1 & 12 & 2 & 6 & - & 3 & 1 & 2 & - & 1 & - & - & - & 46 \\
\hline & beater & 5 & 10 & - & - & 25 & 1 & - & 2 & - & - & - & - & - & 1 & - & 1 & - & - & 45 \\
\hline & wooden strips & - & - & 4 & - & - & - & - & 2 & - & 1 & - & - & - & - & - & - & - & - & 7 \\
\hline \multirow[t]{4}{*}{ scythe } & snath & 1 & - & - & - & - & - & - & - & - & - & - & - & - & - & - & - & - & - & 1 \\
\hline & grip & - & - & - & - & - & - & - & - & - & 1 & - & - & - & - & - & - & - & - & 1 \\
\hline & brace & 2 & - & - & - & - & - & - & - & - & - & - & - & - & - & - & - & - & - & 2 \\
\hline & $\operatorname{arch}$ & - & 1 & - & - & - & - & - & - & - & - & - & - & - & - & - & - & - & - & 1 \\
\hline gambrel & & 1 & 9 & 1 & - & 2 & 4 & - & 2 & - & - & - & - & - & - & - & - & - & - & 19 \\
\hline
\end{tabular}


Tab. 5 - Results of saws and sledges.

\begin{tabular}{|c|c|c|c|c|c|c|c|c|c|c|c|c|c|}
\hline Product & Part of product & $\underset{8}{5}$ & $\underset{\substack{\mathfrak{Z} \\
\mathfrak{Z}}}{\mathfrak{s}}$ & 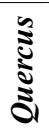 & $\frac{\mathfrak{5}}{\mathfrak{5}}$ & 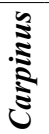 & $\frac{\grave{J}}{\mathrm{~J}}$ & : & $\underset{\mathbf{S}}{\mathbf{\Xi}}$ & 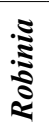 & $\frac{\mathfrak{d}}{\nabla}$ & $\underset{\mathbf{E}}{\mathbf{\Sigma}}$ & 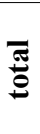 \\
\hline freight & runner & 2 & 4 & 6 & - & - & 2 & - & 2 & - & - & 6 & 22 \\
\hline \multirow[t]{2}{*}{ sledge } & piece of bearing construction & 23 & 26 & 15 & - & 1 & 1 & - & 2 & 12 & - & 2 & 82 \\
\hline & piece of seating & - & - & - & - & - & - & 4 & - & - & 3 & - & 7 \\
\hline two-handed & grip & 6 & 5 & - & 1 & - & 2 & 2 & 1 & - & - & - & 17 \\
\hline \multirow[t]{2}{*}{ saw } & wedge & - & - & 1 & - & - & - & - & - & - & - & - & 1 \\
\hline & handle & - & 1 & - & - & - & - & - & - & - & - & - & 1 \\
\hline \multirow[t]{4}{*}{ frame saw } & shorter part & 1 & 2 & - & - & - & 2 & - & - & - & 1 & - & 6 \\
\hline & longer part & - & 2 & - & - & - & 2 & - & - & - & 2 & - & 6 \\
\hline & repair & - & 1 & - & - & - & - & - & - & - & - & - & 1 \\
\hline & pin & - & - & - & - & - & 1 & - & - & - & - & - & 1 \\
\hline standing & stand & - & - & 1 & - & - & - & - & - & - & - & - & 1 \\
\hline \multirow[t]{4}{*}{ frame saw } & brace & 1 & - & - & - & - & - & - & - & - & - & - & 1 \\
\hline & vertical & - & - & - & - & - & - & - & 1 & - & - & - & 1 \\
\hline & upper bar & - & - & - & - & - & - & - & 1 & - & - & - & 1 \\
\hline & pin & - & - & - & - & - & - & - & 1 & - & - & - & 1 \\
\hline
\end{tabular}

There were 35 pitchforks, the sample number totaling to 150 . The handle always formed the central tooth, with two side teeth; most pitchforks had one brace; two pitchforks had four side teeth; one had three braces; and two pitchfork samples (with a different construction) were used for manure. The handles, and also the central tooth, were made predominantly from beech (19 handles) and ash (14 handles). The bent teeth were constructed from ash (35 teeth), and beech (33 teeth). The same materials were chosen to craft the braces, beech ( 25 braces) and ash (12 braces). There were 13 all-beech pitchforks and ten all-ash pitchforks (Tab. 4).

Forty-six flails were sampled from the museum. These tools usually consisted of two parts, including the shaft (handle) and the "beater", and some flails had wooden strips around the upper end of the beater. In total,

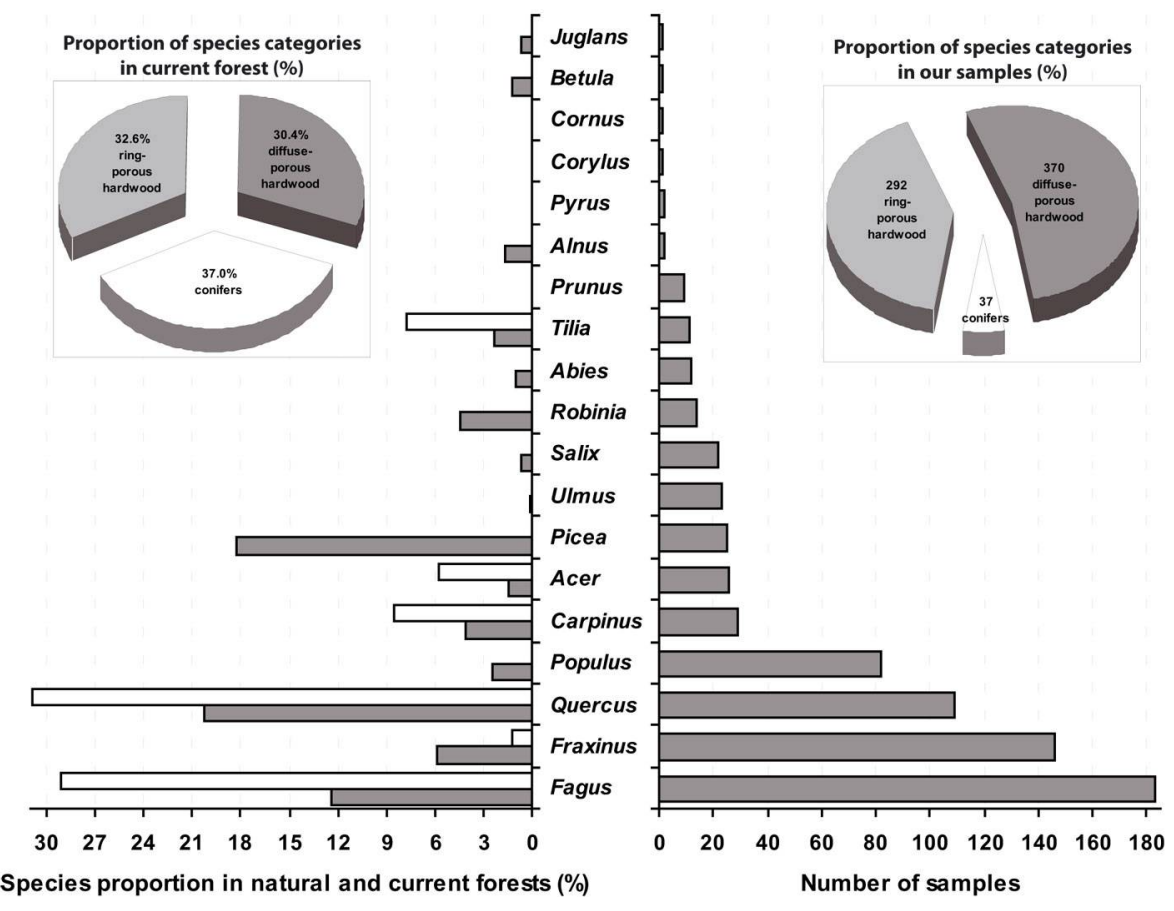

Fig. 3 - The proportion of species identified from samples, compared to current and native forest species composition. Right bar graph depicts proportion of individual species identified from samples, e.g., farming tools, implements, wooden products in Strážnice (on the right). Right pie chart indicates proportions of species categories from samples. Left bar graph compares proportion of current species composition (grey) and historic native (white) forest species composition in the Slovácko region (the South-Moravian Depression and White Carpathians/Vizovice Hills). Left pie chart indicates proportion of species categories in current forests (UHUL 2013).
98 flail samples were obtained. Shafts were made from twelve different species, primarily spruce (Tab. 4). The beaters were predominantly made from hornbeam (25), followed by ash (10), beech (5), elm (Ulmus - 2), maple (1), and interestingly, pear (1) and dogwood (Cornus - 1). The wooden strips were exclusively made of oak. None of the flails was made entirely of one species, they were all made of combinations of two species (not including the wooden strips). The most frequent combinations were spruce used for shafts and hornbeam used for beaters, or beech used for shafts and hornbeam used for beaters (six pieces each).

The museum collection houses one scythe for corn. This special scythe had a beech snath (the shaft), a black locust (Robinia pseudoacacia) grip, two beech braces, and a bent arch of ash (Tab. 4).

Nineteen gambrel samples, a simple implement used in hog-butchering were investigated. The implements were mainly made from ash (9) and maple (4), but also hornbeam (2), elm (2), beech (1), and oak (1 - Tab. 4).

Twelve two-handed saws, three frame saws, and one standing frame saw resulted in 28 samples. The two-handed saws only had two grips, constructed primarily of beech (5 grips), and ash (5 grips - Tab. 5). One oak wedge and one additional ash handle were identified. Only three saws had both grips crafted from the same material (beech, spruce, and ash). The frame saws consisted of two shorter and two longer wood pieces made predominantly of maple and ash (four each), with one repaired ash piece, and one maple pin. The standing frame saw had an oak stand (lower bar), a beech brace, and an elm vertical piece, upper bar, and pin.

The museum housed freight sledges with two runners, several braces, and props ("bearing construction"). Two were constructed with seats made of spruce and fir planks, and one of the seats included a spruce back. Altogether, we sampled 11 freight sledges, which yielded 111 wood samples. The runners were predominantly oak and Prunus (likely $P$. domestica - six pieces for each species). The bearing construction was predominantly ash (26) and beech (23 - Tab. 5).

It was necessary to consider species availability to determine why specific wood was used for utilitarian purposes. Therefore, we examined forest species composition in the area. A comparison of the number of museum specimens representing historical native and current species composition in the region, calculated from data of the two regional forest areas (i.e., the South-Moravian Depressions and White Carpathians/Vizovice Hills - UHUL 2013) is depicted in Fig. 3. The trees growing outside forests and gardens were not included because data was not available.

Species mechanical and physical properties 
are also important, and depend on species density. Therefore, based on literature (Grosser 1977, Wagenführ 2000), we explored density of identified species in a range of density categories (Fig. 4). The first was between $401 \mathrm{~kg} \mathrm{~m}^{-3}$ and $450 \mathrm{~kg} \mathrm{~m}^{-3}$, represented primarily by poplar, followed by spruce and fir. The largest group of species exhibited densities in the $601-700 \mathrm{~kg} \mathrm{~m}^{-3}$ range. This group included the hardwood species oak and beech, which are native to the region, among other hardwood taxa (Fig. 3). Three density categories (between 451-600 $\mathrm{kg} \mathrm{m}^{-3}$ ) between these two well represented species groups, included, in addition to linden, alder, and maple, largely Scots pine (Pinus sylvestris) and larch (Larix decidua), which are not native to the region.

\section{Discussion}

Results indicated 19 woody tree species were used to craft the 337 various tools and implements analyzed in our study. Comparisons of specific samples from our study with the literature showed congruences and inconsistencies. Pavlištík (2011) reported chiseled out products, including wooden tubs for various purposes were made from a mid-splintered stem; and remnants of tree stems after tub production were used to make small shovels, e.g., for flour, and small containers. The most suitable material used for chiseled out products was linden tree wood; however, poplars and willows were also chosen. Havelka (1928) reported the species most commonly used for chiseled out products were maple, alder, beech, hornbeam, and birch. The chiseled out specimens in the Slovácko region analyzed in the present study were largely made of poplar, and to a lesser extent, willow (Tab. 2). The explanation for the discrepancy is difficult to determine, as all of these species have similar properties important for chiseling, i.e., low density (Fig. 4), easy workability and cleavability, and durability in dry environments (e.g., Jirout 1928). Poplar and linden proportions in the regional forest species composition were comparable (Fig. 3). The Slovácko region has a high proportion of floodplains, where poplar and willow are characteristic of the plant communities, so these species were readily available. The tubs and manger constructed from planks were made of spruce and fir (Tab. 2), although they were made by the same craftsmen (Šplíchal \& Otavová 2011). These results were fully congruent with previous findings (Pichler et al. 2009), which revealed manger bottoms discovered in archaeological sites from the $13^{\text {th }}$ century in Austria were made from spruce and fir. Results from large peels ( 30 peels in Strážnice; 20 crafted from beech and five from poplar - Tab. 2), which were partially chiseled and produced from one piece, corresponded to the litera-

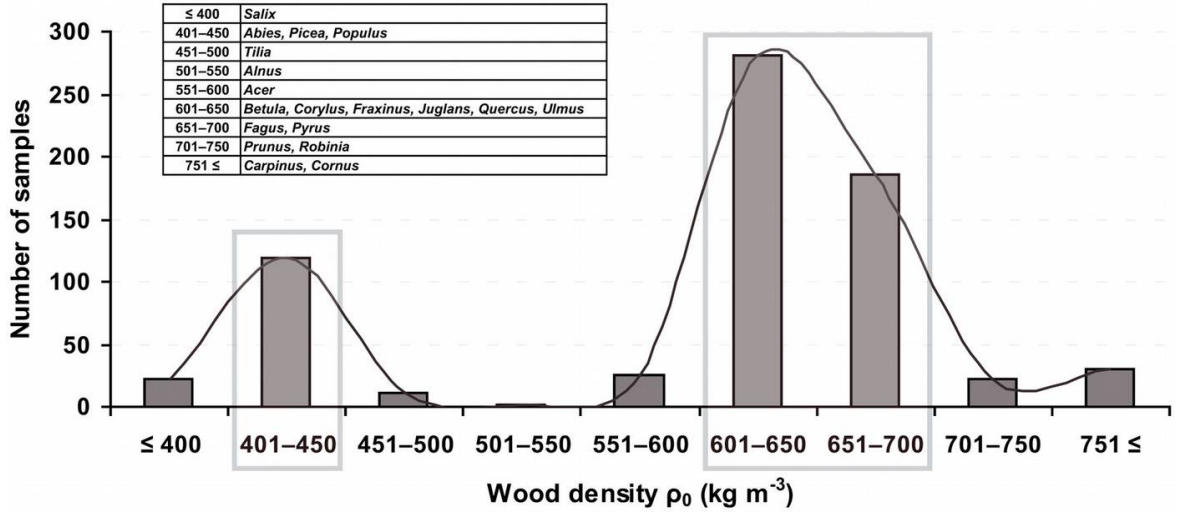

Fig. 4 - Species density categories. The distribution of analyzed species/genera in density categories based on Grosser (1977) and Wagenführ (2000 - top left table), and the number of samples in specific density categories.

ture, which reported large peels were made from poplar as well as beech (Havelka 1928, Pavlištík 1998, 2011, Šimša 2005). A very large tree was necessary for peel production, because one quarter of a tree was required for the peel width, as the implements were partially chiseled out of one complete piece of wood (Šimša 2005).

According to the literature, coopers predominantly used oak wood; however, they also used wood from large fir and spruce trees without defects that grew slowly. Coopers made containers of various shapes (round, oval, and egg-shaped) for various purposes, including wooden buckets for bread dough, butter churns, wooden pails, and special wooden buckets used to measure grains. The bottom of the latter was divided into two irregular parts, the larger with $1 / 4$ of the local measure, and the smaller $1 / 2$ that size (Pavlištík 1998, 2011). Whereas local crafts-

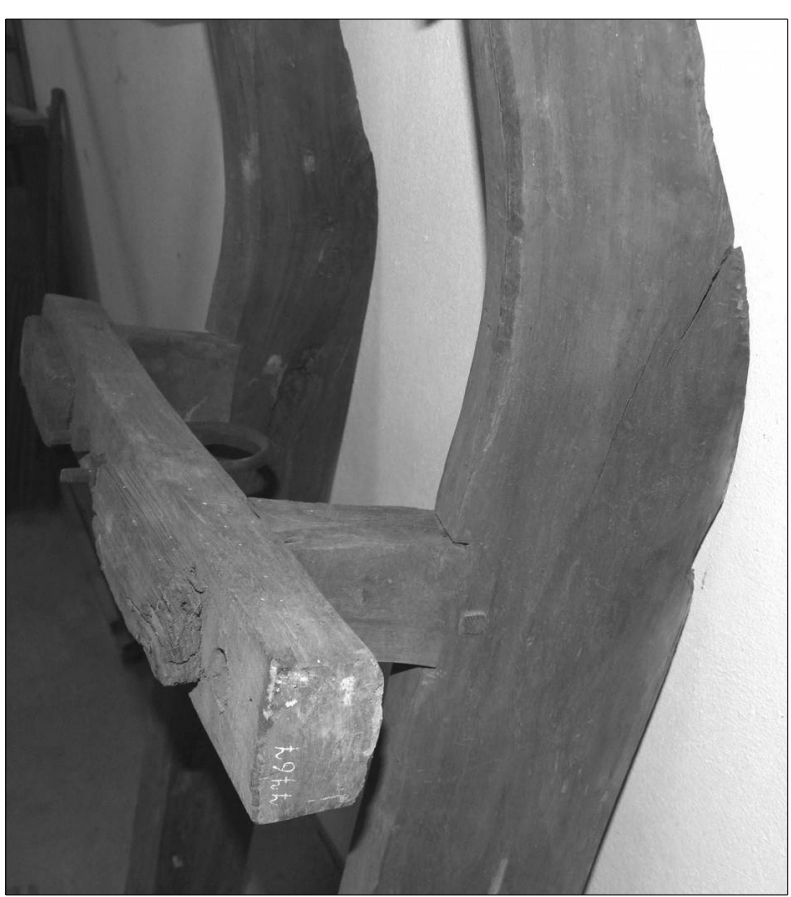

men (villagers) made softwood oval or round-shaped containers with a bottom only (closed on one side), professional coopers in towns constructed containers closed on two sides made of oak (Pavlištík 2011). Šplíchal \& Otavová (2011) showed different craftsmen (called Weissbinder or Fassbinder in German) made softwood containers rather than oak and beech containers (called Bötcher or Schwarzbinder). However, these two crafts merged in the mid- $19^{\text {th }}$ century. Nearly all coopers' products in our sample set were made of oak ( $96 \%$ - Tab. 3), and this was likely due to the high proportion of oak in the surrounding floodplain forests. We can also assume that Strážnice coopers were professionals, and people from surrounding villages purchased wooden buckets and pails from these craftsmen. There is another possible source of the coopers' products. At the end of the $19^{\text {th }}$ century, the disparities bet-

Fig. 5 - Cracked freight sledge runner made from plum (Prunus domestica) wood. 
ween regions in south-eastern Moravia in creased. People from less fertile regions (e.g., northern areas) were forced to make a non-agricultural living, and people from fertile regions (Slovácko one of them) concentrated on agriculture. Subsequently, it made sense to purchase specialized products from craftsmen who made a living in the production of wooden implements, tools, and farm and household items (Pavlištík 2011). Evidence of much older oak wooden buckets also comes from Germany. Wrobel \& Eckstein (1985) analyzed archaeological samples from a well in Lübeck, and found bucket-shaped containers were predominantly constructed of oak. Oak was seen as the ideal material for casks, buckets, and barrels, likely due to its mechanical and physical properties. Oak wood manifests large dimensional changes, shrinking and swelling, in the tangential direction (Wagenführ 2000) providing sufficient tightness for liquids. Furthermore, macropores in the heartwood of "white oaks", i.e., Q. robur and $Q$. petraea, the predominant oak species in the Czech Republic, contain tyloses (Wagenführ 2000), which impart low permeability, an undesirable property for impregnation, but an excellent property for tightness. Oak wood is also highly durable, and resistant to mechanical wear (Jirout 1928).

Handles for pitchforks, rakes, and similar tools were made from fir or spruce timber as well as thick hazel (Corylus) branches (Šimša 2005, Šplíchal \& Otavová 2011). Jirout (1928) indicated other species suitable for handles were oak, ash, and beech; however, beech is not suitable for all tools. Our results showed flail and ash rake handles were made from spruce, and one hazel handle was observed (Tab. 4). However, rake and pitchfork handles were predominantly made of beech and ash (Tab. 4). Our observations were inconsistent with the literature. Jirout (1928) reported beech was highly undesirable as a species because it caused friction burns on the hand during use. However, the literature indicated other parts of rakes and pitchforks, e.g., bars, braces and bent teeth, were made of beech and ash (Šimša 2005, Pavlištík 2011). Pitchforks for manure and beets (Fig. 2) were made from the same materials, but constructed differently (Šimša 2005, Pavlištík 2011). Beech and ash were species most easily and often bent (Jírů 1952). Rake handles found in the region were split in the middle, and bent apart. Pitchfork teeth were also bent, and as previously noted, the central tooth of pitchforks was formed from the handle; therefore, the handle was bent to form the lower central tooth. As coniferous species aged when used in implements, wood fragments wore off causing users to get splinters. However, beech was easy to work for craftsmen, and safe for use. Birch, walnut (Juglans), and
Prunus teeth in some rakes most likely indicated clever use of cultivated garden species. Furthermore, one rake specimen was a conglomerate of six species; walnut and Prunus comprised the teeth, the two handles were ash, the bar was elm, and the braces were each oak and poplar. Careful examination showed the teeth were originally made of walnut, and later, one tooth was replaced with Prunus. This specimen was a unique original implement made by a farmer himself.

Jirout (1928) was the only reported information regarding flail construction material; and was limited to the beaters, which were made from hornbeam, as this species was one of the hardest, sturdiest and strongest available. The museum flails were crafted from the largest variety of species (12 species) compared to all other museum samples examined. In addition to spruce and hazel handles, 10 more species were chosen from the local area for handle construction, and seven species were used for beaters. The wood choice for beaters indicated viable knowledge of the hardest species. In addition to hornbeam, which is described in the literature (Jirout 1928), ash, and beech were also chosen. Clever and appropriate use of garden species was also detected. Pear and dogwood, the latter having increased density (880-1030 $\mathrm{kg} \mathrm{m}^{-3}$ - Grosser 1977) than hornbeam $\left(790 \mathrm{~kg} \mathrm{~m}^{-3}\right.$ - Grosser 1977) were used in tool construction. Havelka (1928) reported hornbeam and pear wood were the species used for "presses", which we interpreted as pressed or pressing equipment parts.

The literature indicated scythes, including simple grass and more elaborated corn scythes, were made from beech, ash, and maple wood. The most elaborate types used for scything corn were constructed of a snath (the shaft), one or two grips, two braces, and an arch, i.e., the bent part of the scythe (Pavlištík 2011). This type corresponded to our results, as our one specimen had a beech snath, a black locust grip, beech braces, and a bent ash arch.

The same materials used for handles of other implements, i.e., beech, ash, and oak were used for gambrels (Šimša 2005). The museum specimen gambrels were primarily constructed of ash, used for the handles, but other species were also used to craft these tools (Tab. 4). Gambrels required primarily strong, resilient, and flexible wood due to the need for increased mechanical loading. Results showed properties of the species used to construct most specimens met this requirement, with the exception of the low flexibility of beech (used only once).

Jirout (1928) reported hornbeam was the most suitable material for frame saws. The frame saws in the present study were made from oak, beech, and elm. The saw bars were predominately crafted from beech, ash, and maple. The saws only consisted of short and narrow wood pieces, it appeared the wood materials used for handles were of minor importance compared to metal parts, and remnants of other tools might have been used in saw construction. However, the wood species used in saw making were hard, i.e., high density wood. This is an important feature of a tool that will be used frequently, and with force.

Elm and ash were described as suitable species for sledge construction (Jirout 1928). Filkova et al. (2012) analyzed a freight sledge found in the Boskovicko region (Czech Republic), and determined it was made of beech. Freight sledge construction requires strength and stiffness for the entire tool weight bearing. The sample species composition resulting from our analyses included species corresponding to implement function, particularly ash and beech. The other species exhibited high densities, including black locust, oak, elm, maple, and hornbeam. In addition, again a cultivated garden species was identified, which was Prunus. Although Prunus species are difficult to distinguish using this methodology, we assumed the species was Prunus domestica L. (plum), as plum growing has a longstanding tradition in (and around) the region (Rop et al. 2009). Plum is also the most common Prunus in central Europe (Herzog 1998). The bent runners were constructed from wood species that were easily bent, including oak, ash, beech, elm, and maple. It is interesting craftsmen used plum wood for runners, because although its wood has a high density and strength, it is also susceptible to cracking (Jirout 1928, Němec et al. 2005). For example, the museum specimen sledge in Fig. 5 shows cracks developed in plum wood.

The farming and household tools and implements, and other wooden objects used by inhabitants of the Slovácko region were crafted predominantly from wood species with higher densities (Fig. 4), and therefore better mechanical properties. The greatest number of species (eight taxa), including beech, oak, and ash represented the $601-700 \mathrm{~kg} \mathrm{~m}^{-3}$ density category. These species exhibited suitable properties to craft necessary utilitarian objects, and were available in regional forests, riparian zones, and floodplains (Fig. $3)$. The high low-density $\left(351-450 \mathrm{~kg} \mathrm{~m}^{-3}\right)$ species representation results from chiseled out samples (wooden tubs and troughs), where poplar and willow were primary species used in crafting the objects. Species with 451-600 $\mathrm{kg} \mathrm{m}^{-3}$ densities (linden, alder and maple) were chosen for use only rarely. This category also included Scots pine and larch, however none of our museum specimens were crafted from these species. These species are in high proportions in the current forests of the region (notably Scots pine), 
but were negligible in the native historic forest species composition (UHUL 2013), and are neither floodplain nor cultivated garden species. In addition, spruce, which is currently the most frequently used wood species, was only sporadic.

Contemporary comparisons showed modern manufacturers tend to use metal and plastic instead of wood. Products parts if made of wood, e.g., usually handles, are constructed from "economic" species, including beech, spruce, linden, and ash. However, sustainable production practices, together with the conversion of monoculture forests to mixed forests could change manufacturing approaches. Wood is a renewable resource and an environmentally safe material, unlike metals and plastics. Knowledge of its proper use for various applications should be explored, and educational outreach facilitated to regional communities to propose new forestry based opportunities.

We conclude that regional inhabitants during the $18^{\text {th }}$ and $19^{\text {th }}$ centuries chose a variety of wood species with suitable properties to craft tools, implements, and utilitarian farm and household objects with specific features. Some parts were likely made from remains of primary construction, and easily available trees. Craftsmen used regional species with desirable attributes within and outside forest boundaries. For the Slovácko region, the collection area extended to floodplain, riparian, and cultivated garden species, which today, are used only by specific professions, e.g., folk art carvers. Fruit tree wood is otherwise used primarily as firewood, due to our ignorance of other possible uses. However, with the growing conversion of monoculture forests to mixed forests, and with the current emphasis on sustainable forest development, it is vital to explore and document the historical roles of wood species.

\section{Acknowledgments}

This study was accomplished with support of project IGA no. 24/2012 "Historical Utilization of Wood - Data Collection", and with funding from the Czech Republic Grant Agency, Projects No. 13-04291S and P405/ $11 / 1729$. We would also like to thank the employees of the Museum of Village of south-east Moravia, and the National Institute of Folk Culture NULK, Martin Šimša and Martina Zezulová, for their permission, assistance, and cooperation. We also thank Jarmila Šlezingerová for help with identifications.

\section{References}

Eckstein D, Wrobel S (2007). Dendrochronological proof of origin of historic timber - retrospect and perspectives. In: Proceedings of the
"DENDROSYMPOSIUM 2006 TRACE - Tree Rings in Archaeology Climatology and Ecology", vol. 5 (Haneca K, Verheyden A, Beekmann H, Gärtner H, Helle G, Schleser G eds). Tervuren (Belgium) 20-22 April 2006. Schriften des Forschungszentrums Jülich, Reihe Umwelt, vol. 74, pp. 8-20.

Filková V, Rybníček M, Kolár T, Pokorný J (2012). New open air museum in Moravia - anatomical identification of wood. In: Proceedings of the "Archaeological and Historical Wood Utilization Conference" (Lange $S$, Hänninen $K$, Vermeeren $\mathrm{C}$ eds). Egmond aan Zee (the Netherlands), 28-30 September 2012. BIAX Consult, Biologische archeologie \& Landschapsreconstructie, pp. 15 .

Grosser D (1977). Die Hölzer Mitteleuropas [The woods of Central Europe]. Springer-Verlag, Berlin, Heidelberg, New York, pp. 208. [in German] Havelka VV (1928). Jaké dríví vykazuje lesník $r$. 1823 remeslníkum lidovým [Which timber is reported by a forester for folk craftsmen in 1823]. Ceský lid 28: 349-357.

Herzog F (1998). Streuobst: a traditional agroforestry system as a model for agroforestry development in temperate Europe. Agroforestry Systems 42: 61-80. - doi: 10.1023/A:1006152127824

Hoadley RB (1990). Identifying wood: accurate results with simple tools. Taunton Press, Newtown, CT, USA, pp. 223.

Holec F (1971). Obchod se drívím v Praze ve 14.17. století [Timber trade in Prague in $14^{\text {th }}-17^{\text {th }}$ centuries]. In: "Pražský sborník historický [Proceedings of historical Prague" (Holec F ed). Orbis, Praha, Czech Republic, pp. 5-100. [in Czech]

IAWA Committee (1989). IAWA list of microscopic features for hardwood identification. IAWA Bulletin new series 10: 219-232.

Ives E (2001). A guide to wood microtomy; making quality microslides of wood sections. Suffolk Offset Martlesham Suffolk, UK, pp. 114.

Jirout F (1928). Drevo v prírode a remeslech, v živnosti a prumyslu vubec [Wood in nature and crafts, business and industry]. Industrial Publishing House, A. Neubert, Prague, Czech Republic, pp. 669. [in Czech]

Jírů P (1952). Všeobecná technologie dreva [General timber technology]. Prague, Czech Republic, pp. 169. [in Czech]

Lipský Z (2000). Sledování zmen v kulturní krajine [Tracking changes in the cultural landscape]. Institute of Applied Ecology, CZU, Kostelec nad Cernými lesy, Czech Republic, pp. 71. [in Czech]

Nemec J, Janáček V, Hurda B (2005). Drevo - historický lexikon [Wood - a historical lexicon]. Grada Publishing, Prague, Czech Republic, pp. 80. [in Czech]

Pavlištík K (1998). Práce ze dreva III. - část 1 [Work from timber III - part 1]. Institute of Popular Culture, Strážnice, Czech Republic, pp. 68. [in Czech]

Pavlištík K (2011). Drevo, proutí, sláma v tradiční rukodelné výrobe na Podrevnicku [Wood, wicker, straw traditional handicraft production in Podrevnicko]. Museum of Southeast Moravia, Zlín, Czch Republic, pp. 279. [in Czech]

Pichler T, Nicolussi K, Goldenber G (2009). Dendrochronological analysis and dating of wooden artefacts from the prehistoric copper mine Kelchalm/Kitzbühel (Austria). Dendrochronologia 27 (2): 87-94. - doi: 10.1016/j.dendro.2009. 06.003

Pruša E (1990). Prirozené lesy CR [Natural forests of the Czech Republic]. SZN, Prague, Czech Republic, pp. 248. [in Czech]

Rop O, Jurikova T, Mlcek J, Kramarova D, Sengee $Z$ (2009). Antioxidant activity and selected nutritional values of plums (Prunus domestica L.) typical of the White Carpathian Mountains. Scientia Horticulturae 122 (4): 545-549. - doi: 10.1016/j.scienta.2009.06.036

Schweingruber FH (1990). Anatomy of European woods. An atlas for the identification of European trees, shrubs and dwarf shrubs. Paul Haupt Publisher, Berne, Switzerland and Stuttgart, Germany, pp. 800.

Simša M (2005). Práce ze dreva III. - část 3 [Work from timber III - part 3]. National Institute of Popular Culture, Strážnice, Czech Republic, pp. 49. [in Czech].

Splíchal V, Otavová M (2011). Poselství dreva [Message from wood]. Golempress, Letohrad, Czech Republic, pp. 703. [in Czech]

Tarp P, Helles F, Holten-Andersen P, Larsen JB, Strange N (2000). Modelling near-natural silvicultural regimes for beech'an economic sensitivity analysis. Forest Ecology and Management 130: 187-198. - doi: 10.1016/S0378-1127(99)00 190-5

UHUL (2013). Revised 2013. UHUL Forest Management Institute, web site. [in Czech] [online] URL: http://www.uhul.cz/index.php

Vavrčík H, Gryc V (2004). Metodika výroby mikroskopických preparátu ze vzorku dreva [Method for microscopic preparation production from timber samples]. Acta Universitatis agriculturae et silviculturae Mendelianae Brunensis / Acta of Mendel University of agriculture and forestry Brno 4: 169-175. [in Czech]

Vinar J, Kyncl J, Ružička P, Zák J (2005). Historické krovy II. - pruzkumy a opravy [Historic trusses II - surveys and repairs]. Grada, Prague, Czech Republic, pp. 301. [in Czech]

Wagenführ R (2000). Holzatlas [Wood Atlas]. Fachbuchverlag Leipzig im Carl Hanser Verlag, Munchen, Germany, pp. 707. [in German]

Wrobel S, Eckstein D (1985). On the evidence derived from the anatomical analysis of wooden remains from archaeological excavations. In: Proceedings of the 3rd "Nordic conference on the application of scientific methods in archaeology - ISKOS 5" (Edgren T, Jungner H eds). Mariehamn, Åland (Finland), 8-11 October 1984. The Finnish Antiquarian Society, Helsinki, Finland, pp. 211-216. 